\title{
MONITORING AND TREATMENT OF VOLATILE ORGANIC COMPOUNDS IN DRINKING WATER COMPARATIVE STUDY
}

Kandile, Nadia, Gh. ${ }^{(1)}$; Hewehy, M. I. ${ }^{(2)}$ and Abdel-Hady, E. Z. ${ }^{(3)}$

1) Faculty of Women, Chemistry Department, Ain Shams University 2) Env. Basic Science Department, Institute of Environmental Studies \& Research, Ain Shams University 3) Holding Company for Water and Wastewater, Cairo, Egypt.

\begin{abstract}
Volatile organic compounds (VOCs) present in drinking water, have a negative impact on human health and environment especially that formed during chlorination step in the treatment process, they classified as possible human carcinogens, when exceed the permissible limits. The identification and quantification of VOCs performed by purge \& trap GC/MS instrument, using reference analytical method (EPA 524.2, 1995). A monthly monitoring comparative study established during 2016 in both input and output of Shubra El-Kheima (Water Treatment Plants WTP) (1 km far from Nile River on AlSharqawia canal at the northern border of capital Cairo) and South Alamein WTP $(270 \mathrm{~km}$ downstream far from the Nile River on Alhamam canal at North Coast of Egypt). The study investigated and recorded the presence of disinfection by-product of Volatile Organic Compounds (DBPs-VOCs) $\left(\mathrm{CHCl}_{3}, \mathrm{CHCl}_{2} \mathrm{Br}, \mathrm{CHClBr}_{2}\right.$ and $\left.\mathrm{CHBr}_{3}\right)$ which exceeded the permissible limits in the produced Water of South Alamein WTP and its boosters. The study succeeded in estimating the amount of granular activated carbon GAC required to reduce (DBPs-VOCs) values from $(178 \mu \mathrm{g} / \mathrm{l})$ to $(94 \mu \mathrm{g} / \mathrm{l})$ in the produced water of South Alamein WTP, The duration frequency for changing (GAC)would be approximately (581 ton)/(17 days).
\end{abstract}

Key words: Volatile organic compounds, granular activated carbon, drinking water, disinfection by-product, GC/MS analysis 
J. Environ. Sci.

Institute of Environmental Studies and Research - Ain Shams University

\section{INTRODUCTION}

Volatile organic compounds (VOCs) are a group of organic compounds containing one or more carbon atoms and whose vapor pressures are high enough to cause them to readily volatilize into the atmosphere conditions (Ikem, 2010). Due to the industrial revolution, many activities, such as petroleum industry, have emitted anthropogenic pollutants including toxic gases and volatile organic compounds (VOCs) (Hailin et al., 2013). VOCs can produce from,

1. Industrial Chemicals discharge and human dwellings: Such as: $1,3-$ dichlorobenzene, ethylbenzene, 1,1-dichloroethane, 1,1-dichloroethene, hexachlorobenzene, dichloroethene, dichloromethane, methyltertiarybutylether, monochlorobenzene, trichlorobenzenes, 1,1,1-trichloroethane, benzene, Carbon tetrachloride, 1,2-dichlorobenzene, 1,4-dichlorobenzene, 1,2-dichloroethane, 1,2- hexachlorobutadiene, styrene, tetrachloroethene, toluene, trichloroethene, xylenes.

2.Agricultural activity: Such as: 1,2-dibromo-3-chloropropane, 1,3dichloropropene, 1,2-dichloropropane, 1,2-dibromoethane.

3. Disinfection processes with chlorine: Such as: chloroform, bromodichloromethane, dibromochloromethane and bromoform (WHO, 2011).

In 1881, a German named Koch showed the role of bacteria in waterborne diseases. Koch demonstrated that minute quantities of chlorine could inactivate harmful waterborne pathogens. The introduction of chlorination resulted in significant decreases in worldwide waterborne 
diseases, such as typhoid, (Haas and Aturaliye, 1999). Chlorine is the most widely and easily used as disinfectant, and the most affordable of the drinking water disinfectants. Similarly, it is an affordable oxidant (WHO, 2004). The most common form of chlorine for use in water treatment plants is the chlorine gas, it is very strong oxidizing agent (more powerful than oxygen), easy to feed, effective disinfection and has a long history of use to reduce water born disease by inactivating harmful microorganism (Salama, 2004). Disinfection by-products DBPs formed due to a reaction between a disinfecting agent (chemical or physical) and a precursor chemical in the source water. The factors affecting formation of DBPs are chlorine residual, contact time, $\mathrm{pH}$, temperature, and natural organic matters NOMs. Chlorine dose from 2.0 to $16.0 \mathrm{mg} / \mathrm{L}$ will lead to an increase of reactions, therefore causing an increase of trihalomethanes THMs and haloacetic acids HAAs formation (Sun et al., 2009). Volatile organic compounds (VOCs) including (THMs) may present in bottled and tap waters at unacceptable concentrations. Several research articles have reported the occurrence of industrial chemicals or disinfection by-products (DBPs) in source, bottled and tap waters (Leivadara et al., 2008; Panyakapo et al., 2008; Wang et al., 2007; Kavcar et al., 2006; Uyak, 2006; Kruawal et al., 2005; Panyapinyopol et al., 2005). Natural organic matter (NOM) is present in all surface, ground waters and soil. NOMs consist of a wide range of compounds, from largely aliphatic to highly colored and aromatic, as well as highly charged to uncharged, having also a wide variety of chemical compositions and molecular sizes. The amount of NOM in water differs with climate and the hydrological regime as well as a number of other environmental factors. Thus, the character of NOM 
can vary with source and time (season). The main compound of interest is bromodichloromethane, which may be responsible for carcinogenic activity in drinking water while chloroform is cytotoxic and non-carcinogenic at environmental concentrations. Some industrial chemicals such as vinyl chloride, methylene chloride, toluene, ethylbenzene, m-xylene, p-xylene, oxylene, naphthalene may be found in drinking waters due to contamination during the process of production (Water Quality Report, 2007).

Egyptian ministry of health approved guideline values for some VOCs like, vinyl chloride: $0.3 \mu \mathrm{g} / \mathrm{L}, \quad 1,1$-dichloroethene: $30 \mu \mathrm{g} / \mathrm{L}, \quad 1,2-$ dichloroethene $50 \mu \mathrm{g} / \mathrm{L}, 1,1,1$-trichloroethane $70 \mu \mathrm{g} / \mathrm{L}$, carbontetrachloride 4 $\mu \mathrm{g} / \mathrm{L}$, benzene $10 \mu \mathrm{g} / \mathrm{L}$, trichloroethene $20 \mu \mathrm{g} / \mathrm{L}$, 1,2-dichloropropane 20 $\mu \mathrm{g} / \mathrm{L}$, toluene $700 \mu \mathrm{g} / \mathrm{L}$, tetrachloroethene $40 \mu \mathrm{g} / \mathrm{L}$, 1,2-dibromoethane 30 $\mu \mathrm{g} / \mathrm{L}$, chlorobezene $300 \mu \mathrm{g} / \mathrm{L}$, ethyl benzene $300 \mu \mathrm{g} / \mathrm{L}$, xylene $500 \mu \mathrm{g} / \mathrm{L}$, styrene $20 \mu \mathrm{g} / \mathrm{L}, 1,4$-dichlorobenzene $300 \mu \mathrm{g} / \mathrm{L}, 1,2$-dichlorobenzene 1000 $\mu \mathrm{g} / \mathrm{L}$, 1,2-dibromo 3-chloropropane $1 \mu \mathrm{g} / \mathrm{L}$, trichlorobenzene $20 \mu \mathrm{g} / \mathrm{L}$, hexachlorobutadiene $0.6 \mu \mathrm{g} / \mathrm{L}$ and total trihalomethanes $\left(\mathrm{CHCl}_{3}, \mathrm{CHBrCl}_{2}\right.$, $\mathrm{CHBr}_{2} \mathrm{Cl}$ and $\left.\mathrm{CHBr}_{3}\right) 100 \mu \mathrm{g} / \mathrm{L}$ which represent the values of VOCs produced from the disinfection process in this study (Egyptian guidelines, 2007).

The aim of this study is monitoring of VOCs in raw and drinking water of Shubra Al-Kheima and South Alamein WTP, and to find an appropriate way to reduce VOCs when exceeds the permissible limits. 


\section{MATERIALS\& METHODS}

\section{Monitoring of VOCs in Shubra Al-Kheima and South Alamein WTP:}

A comparative study between two water treatment plants, both of them are depending on surface water from the Nile River as original source. The first (Shubra El-Kheima WTP) is located in the nearest point of Nile River branch $(1 \mathrm{~km}$, On Al-Sharqawia canal) at north of capital city (Cairo) to evaluate the maximum load content of VOCs in the far north point of capital either that coming from industrial discharge on the surface water or that formed during the disinfection process. This plant covering an area of (10 $\mathrm{km}$ ) distance far from it. The second (South Alamein WTP) is located in the extremist point of Nile River branch $(270 \mathrm{~km}$, On Al-Hammam canal) at South Alamein in the north coast of Egypt (285 km far from the first location) to evaluate the maximum load of VOCs accumulated along this distance and comparing the results of the two selected plants. From the other hand the second plant is covering an area of $190 \mathrm{~km}$ far from the treatment plant which pumping the produced treated water through closed pipes using 6 boosters. Another comparative study will be carried out on the output water of each booster to assess the effect of distance (more contact time with residual chlorine) on disinfection by-product of volatile organic compounds DBPsVOCs formation. A survey of VOCs monitoring performed in raw water and final treated water (output) for both Shubra Al-Kheima \& South Alamein WTPs and its boosters. 
J. Environ. Sci.

Institute of Environmental Studies and Research - Ain Shams University

\section{Removal of Voss using Granular Activated Carbon (GAC)}

2.1 FIXED-BED Column studies: A continuous flow (laboratory scale apparatus), shown in Fig (1) was used to reduce VOCs in the final treated water of South Alamein WTP that produced in August 2017 (which recorded the highest levels of VOCs). 1st, The final treated water was introduced into the glass column packed with GAC, the flow rates of output water is controlled by a fine restrictor at the end of the glass column and consequently a different contact time with GAC could be applied (from $0.5 \mathrm{~min}$ to $21 \mathrm{~min}$ ). A relation between contact time and \% removal was plotted to choose the appropriate contact time that could be applied on South Alamein WTP. 2nd, another experiment was carried out on the final produced water of South Alamein WTP during August 2017 using the same apparatus and applying the obtained appropriate contact time. A breakthrough curve for $\left(\mathrm{CHCl}_{3}\right.$, $\mathrm{CHBrCl}_{2}, \mathrm{CHBr}_{2} \mathrm{Cl}, \mathrm{CHBr}_{3}$ and TOC) plotted to determine the volume at which the amount of GAC would be exhausted for each 5examined parameters.

\section{Materials}

VOCs analyzer, Varian GC/MS-Detector (Ion Trap 4000) equipped with purge \& Trap unit.

TOC Analyzer Tekmar-Teledyne (Phoenix 8000 UV Persulfate-USA)

A continuous flow apparatus consists of glass column packed with Granular Activated Carbon (GAC) (Chemviron-grade 207EA 12.5*40 US mesh size), the internal diameter of the column is $2 \mathrm{~cm}$ and $45 \mathrm{~cm}$ length, the 
column is filled with $25 \mathrm{~g} \mathrm{GAC}$ (mesh size 12 x $40 \mathrm{US}$, bed depth $\mathrm{H}$ was 16 $\mathrm{cm}$ and density $485 \mathrm{~kg} /$ ton). Fig 1

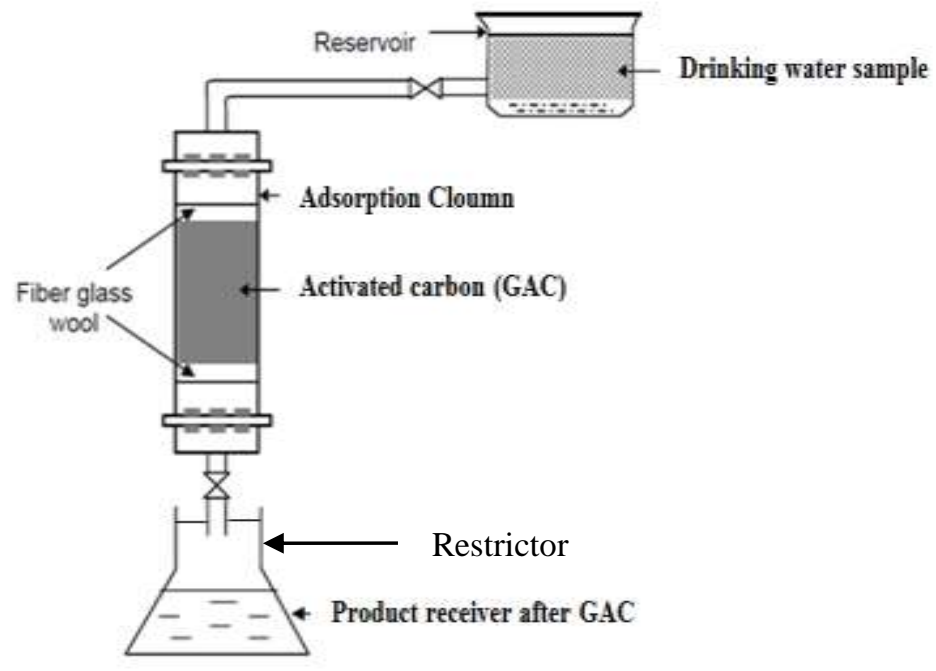

Figure (1): Continuous flow Glass column (laboratory scale setup).

\section{Methods:}

Samples collected from field in $40 \mathrm{ml}$ tightly sealed amber glass bottles. Finally treated drinking water samples, for VOCs preserved by adding $3 \mathrm{mg}$ sodium thiosulfate to stop the reaction of chlorine, $5 \mathrm{ml}$ aliquot injected directly into a Spurger and purged for 11 min then injected to the GC/MS-Ion trap.

VOCs and TOC were monthly monitored and quantified in Shubra AlKheima \& South Alamein WTPs, according to (EPA 524.2, 1995), (Standard method 5310C, 2012) respectively. 
J. Environ. Sci.

Institute of Environmental Studies and Research - Ain Shams University

\section{RESULTSAND DISCUSSIONS}

\section{Monitoring of VOCs \& TOC}

3.1 In Shubra El-Kheima WTP: Monthly monitoring of VOCs (55 species) according to reference method (EPA 524.2, 1995) (Table, 1) and TOC was applied in both raw water (Intake) and final treated water (Product) during 2016

Table 1: Examined VOCs According to reference method (EPA 524.2, 1995)

\begin{tabular}{|c|c|c|c|}
\hline "Hexachlorobutadiene & ב1,2-Dichloroethane & n-Butylbenzene & Dichlorodifluoromethane \\
\hline Vinyl chloride & Trichloroethene & Ethyl benzene & 1,2,4 Trimethylbenzene \\
\hline 1,3 Dichlorobezene & 1,2-dichloropropane & $\begin{array}{l}\text { P-Xylene+M- } \\
\text { Xylene }\end{array}$ & 1,3,5Trimethylbenzene \\
\hline 1,1-Dichloroethene & Dibromomethane & O-Xylene & Bromodichloromethane \\
\hline P-Isopropyletoluene & 1,2 Dichlorobezene & Styrene & Trans1,2-Dichloroethene \\
\hline 1,1-Dichloroethane & 1,4 Dichlorobenzene & Bromoform & $\begin{array}{l}\text { Trichloromonofluoromet } \\
\text { hane }\end{array}$ \\
\hline 2,2-Dichloropropane & Toluene & Isopropylbenzene & Trans1,3-dichloropropene \\
\hline Cis1,2-Dichloroethene & Cis1,3-dichloropropene & Bromobenzene & 1,2,3Trichloropropane \\
\hline Bromochloromethane & $\begin{array}{l}\text { 1,1,2- } \\
\text { Trichloroethane }\end{array}$ & Naphthalene & $\begin{array}{l}\text { 1,2-Dibromo-3- } \\
\text { Chloropropane }\end{array}$ \\
\hline Chloroform & Tetrachloroethene & Sec-Butylbenzene & 1,2,4 Trichlorobenzene \\
\hline 1,1,1-Trichloroethane & 1,3 Dichloropropane & N-Propylbenzene & 1,1,1,2-Tetrachloroethane \\
\hline Carbon tetrachloride & $\begin{array}{l}\text { Dibromochloromethan } \\
\text { e }\end{array}$ & 2-Chlorotoluene & 1,2,3-Trichlorobenzene \\
\hline 1,1-Dichloropropene & 1,2-Dibromoethane & 4-Chlorotoluene & 1,1,2,2-Tetrachloroethane \\
\hline Benzene & Chlorobenzene & Ter-Butylbenzene & \\
\hline
\end{tabular}


Fig (2) shows the absence of the targeted fifty-five VOCs species in the raw water which indicates that (there is no industrial waste load enough to affect the levels of VOCs in this area during the study period), as the main source of VOCs in raw water is industrial waste.

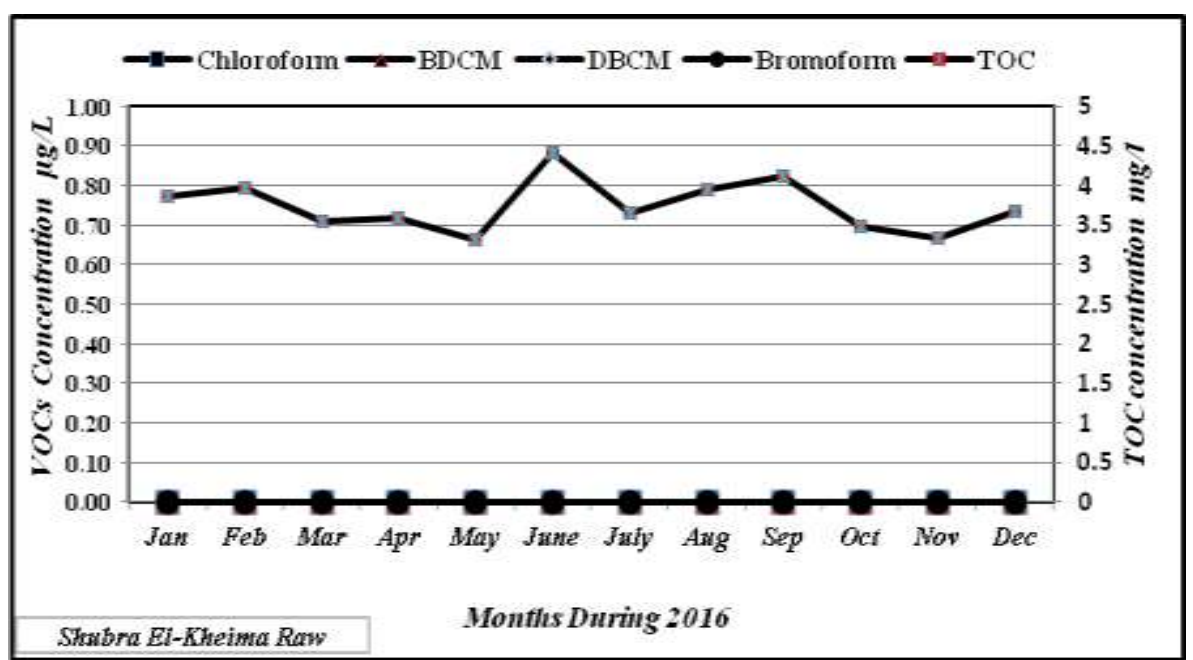

Figure (2): Monthly VOCs \& TOC levels variation in raw water of Shubra El-Kheima WTP during 2016.

Fig (3) shows the absence of fifty-one VOCs species from the final produced water of Shubra El-Kheima WTP, while the four rest compounds of DBPs-VOCs $\left(\mathrm{CHCl}_{3}, \mathrm{CHBrCl}_{2}, \mathrm{CHBr} 2 \mathrm{Cl}\right.$ and $\left.\mathrm{CHBr}_{3}\right)$ showed different levels below the permissible limits of Egyptian guidelines during the study period. These levels were due to the addition of chlorine gas as a disinfectant to raw water in the presence of NOMs which indicated by (Total Organic Carbon TOC) in the Studied plant (Shubra El-Kheima). In addition, Fig (3) shows that the maximum levels of these compounds were recorded in Oct. 2016 as follows $\left(\mathrm{CHCl}_{3} 62.88 \mu \mathrm{g} / \mathrm{l}, \mathrm{CHBrCl}_{2} 19.69 \mu \mathrm{g} / 1, \mathrm{CHBr}{ }_{2} \mathrm{Cl} 5.82 \mu \mathrm{g} / 1\right.$ 
and $\left.\mathrm{CHBr}_{3} 2.26 \mu \mathrm{g} / \mathrm{l}\right)$. Levels of the previous compounds increased because of increasing NOMs (TOC $4.18 \mathrm{mg} / \mathrm{l}$ ) during this month. The minimum levels of these compounds were recorded in May 2016 as follows $\left(\mathrm{CHCl}_{3} 24.97\right.$ $\mu \mathrm{g} / \mathrm{l}, \mathrm{CHBrCl}_{2} 13.21 \mu \mathrm{g} / \mathrm{l}, \mathrm{CHBr}_{2} \mathrm{Cl} 3.73 \mu \mathrm{g} / \mathrm{l}$ and $\left.\mathrm{CHBr}_{3} 0.81 \mu \mathrm{g} / \mathrm{l}\right)$ because of decreasing of NOMs (TOC $3.22 \mathrm{mg} / \mathrm{l}$ ) during this time of year. (Fig, 3)

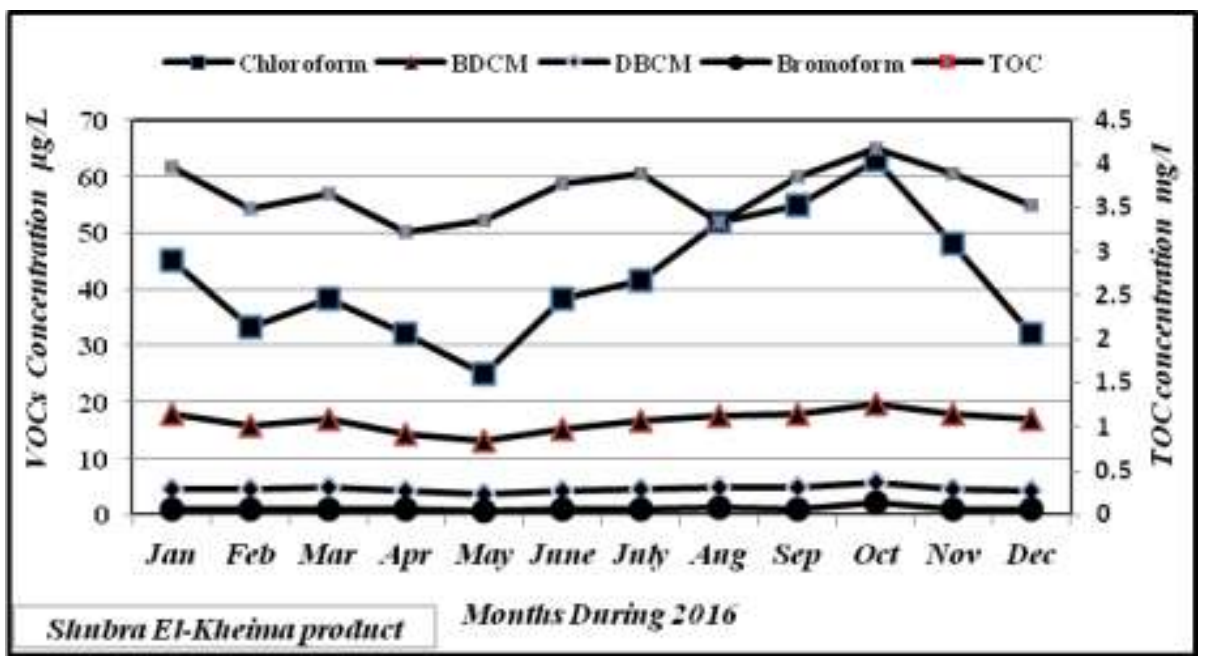

Figure (3): Monthly VOCs \& TOC levels variation in produced water of Shubra El-Kheima WTP during 2016.

3.2 In South Alamein WTP: Monthly monitoring of targeted VOCs \& TOC was applied in both Raw water (Intake) and final treated water (Product) during 2016.

Fig (4) shows the absence of fifty four VOCs compounds during study period in raw water, while the rest compound (Benzene) detected at levels below the maximum permissible limit of Egyptian guidelines at months of (Jan, Feb, and Dec) due to the presence of many water suction pumps along 
El-Hammam canal banks for agriculture purposes which met the winter blockage.

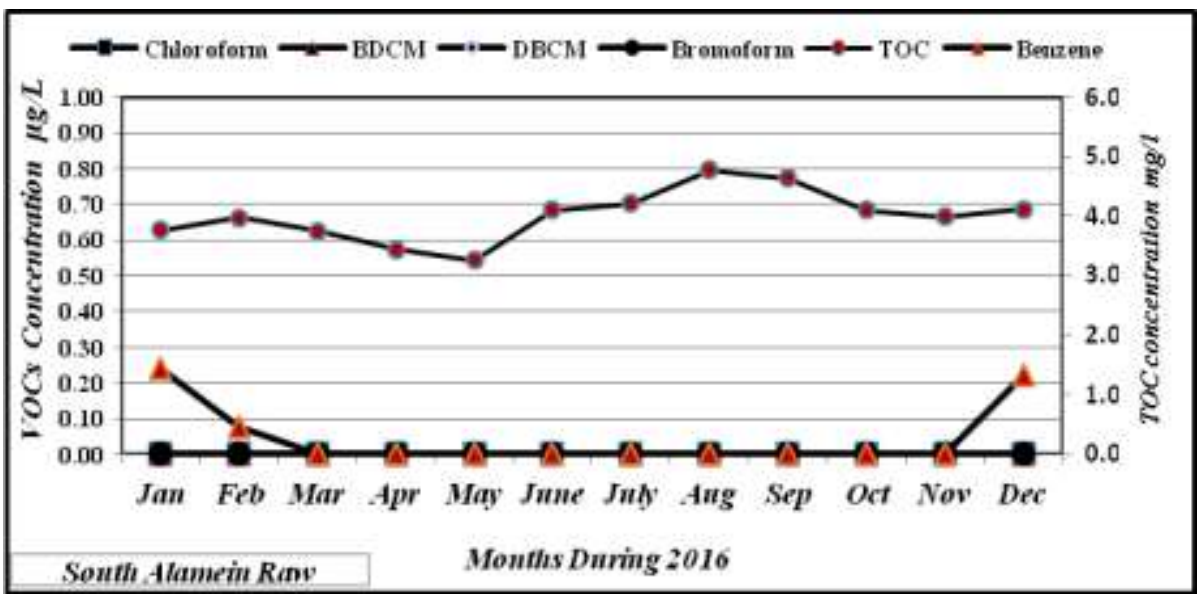

Figure (4): Monthly VOCs \& TOC levels variation in raw water of South Alamein WTP during 2016.

Fig (5) shows the absence of fifty-one VOCs species from the final produced water of South Alamein WTP, while the four rest compounds of DBPs-VOCs $\left(\mathrm{CHCl}_{3}, \mathrm{CHBrCl}_{2}, \mathrm{CHBr} 2 \mathrm{Cl}\right.$ and $\left.\mathrm{CHBr}_{3}\right)$ showed different levels above the permissible limits of Egyptian guidelines during the study period. These high levels were due to the addition of chlorine gas as a disinfectant to raw water in the presence of NOMs in the Studied plant (South Alamein). In addition, Fig (5) shows that the maximum levels of these compounds were recorded in August 2016 as follows $\left(\mathrm{CHCl}_{3} 85.02 \mu \mathrm{g} / \mathrm{l}\right.$, $\mathrm{CHBrCl}_{2} 63.28 \mu \mathrm{g} / 1, \mathrm{CHBr}_{2} \mathrm{Cl} 39.70 \mu \mathrm{g} / \mathrm{l}$ and $\left.\mathrm{CHBr}_{3} 5.17 \mu \mathrm{g} / \mathrm{l}\right)$. Levels of the previous compounds increased because of increasing of NOMs (TOC 4.51 $\mathrm{mg} / \mathrm{l})$ during this month. The minimum levels of these compounds recorded 
in May 2016 as follows $(\mathrm{CHCl} 335.67 \mu \mathrm{g} / \mathrm{l}, \mathrm{CHBrCl} 226.42 \mu \mathrm{g} / \mathrm{l}, \mathrm{CHBr} 2 \mathrm{Cl}$ $21.32 \mu \mathrm{g} / \mathrm{l}$ and $\mathrm{CHBr} 32.44 \mu \mathrm{g} / \mathrm{l}$ ) due to decreasing of NOMs (TOC 3.36 $\mathrm{mg} / \mathrm{l})$ during this time of year.

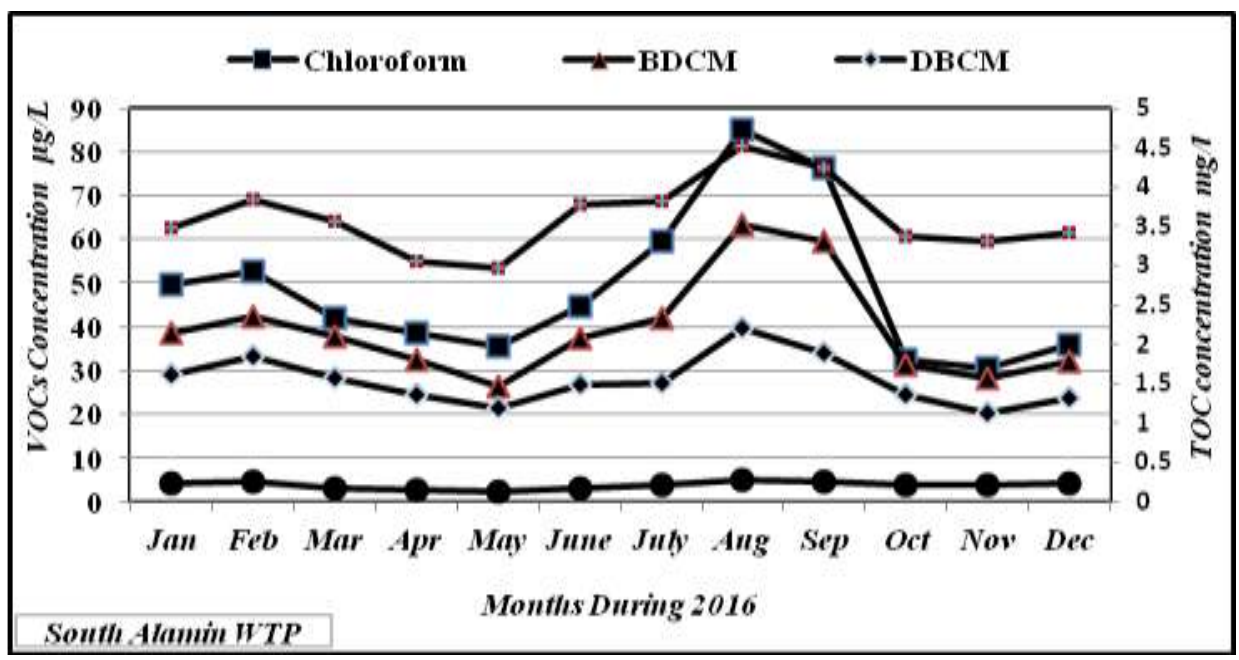

Figure (5): Monthly VOCs \& TOC levels variation in produced water of South Alamein WTP during 2016.

\section{Removal of DBPs-VOCs from the Produced water of South Alamein TWP:}

Using a bench scale Continuous flow Glass column (2 cm I.D), backed with $25 \mathrm{~g} \mathrm{GAC}$ of height $16 \mathrm{~cm}$ (Fig, 1). Different contact times applied to the produced water from south Alamein WTP with GAC (from 0.5 min to 21 min) during August 2017 (monitoring results showed that the maximum level of DBPs-VOCs recorded in August 2016). A relation between contact time and \% removal of DBPs-VOCs \& TOC (as a main precursor of the produced DBP-VOCs) was plotted. 
From Fig (6), we find that the appropriate contact time is $10.0 \mathrm{~min}(0.166$ hr), (with respect to both the \% removal of DBPs-VOCs and TOC). As the maximum output $172000 \mathrm{~m}^{3} /$ day, total surface area of 14 working GAC filters are $498.75 \mathrm{~m}^{2}$, and consequently the linear velocity is $14.37 \mathrm{~m} / \mathrm{hr}$ (total output per hour/total surface area of GAC filters) for South Alamein WTP. The corresponding depth of GAC that give a contact time, (10 min), will be $2.4 \mathrm{~m}$ [Linear velocity $(\mathrm{m} / \mathrm{h}) \mathrm{x}$ appropriate contact time $(0.166 \mathrm{hr})]$.

Table (2): \% removal of analytes from produced water of South Alamein WTP with different contact time with GAC in glass column during August 2017.

\begin{tabular}{|c|c|c|c|c|c|c|c|c|c|c|c|c|c|}
\hline \multirow[b]{2}{*}{$\mathrm{No}$} & \multirow[b]{2}{*}{ Sample Name } & \multirow[b]{2}{*}{$\begin{array}{c}\text { Contact } \\
\text { Time } \\
(\mathrm{min})\end{array}$} & \multicolumn{3}{|c|}{ TOC } & \multicolumn{2}{|c|}{$\mathrm{CHCl}_{3}$} & \multicolumn{2}{|c|}{$\mathrm{CHBr} \mathrm{CL}_{2}$} & \multicolumn{2}{|c|}{$\mathrm{CHBr}_{2} \mathrm{CL}$} & \multicolumn{2}{|c|}{$\mathrm{CHBr}_{3}$} \\
\hline & & & $\mathrm{mg} / \mathrm{l}$ & $\begin{array}{c}\text { Amount } \\
\text { Removed } \\
\text { mg/l }\end{array}$ & 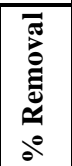 & $\mu \mathrm{g} / \mathrm{l}$ & 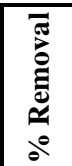 & $\mu \mathrm{g} / \mathrm{l}$ & 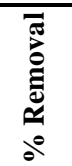 & $\mu \mathrm{g} / \mathrm{l}$ & 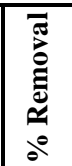 & $\mu g / 1$ & 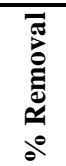 \\
\hline 1 & Blank Before GAC & & 0.03 & & & 0.00 & & 0.00 & & 0.00 & & 0.00 & \\
\hline 2 & Blank After GAC & 30.00 & 0.02 & & & 0.00 & & 0.00 & & 0.00 & & 0.00 & \\
\hline 3 & $\begin{array}{c}\text { Alamine Product } \\
\text { Before GAC }\end{array}$ & & 4.50 & & & 80.00 & & 58.00 & & 36.00 & & 4.90 & \\
\hline 4 & \multirow{11}{*}{$\begin{array}{c}\text { South Alamein } \\
\text { WTP Product } \\
\text { After GAC }\end{array}$} & 0.50 & 3.50 & 1.00 & 24.2 & 5.48 & 93.2 & 2.46 & 95.8 & 1.72 & 95.2 & 0.12 & 97.6 \\
\hline 5 & & 0.75 & 3.25 & 1.25 & 29.7 & 3.46 & 95.7 & 1.32 & 97.7 & 0.53 & 98.5 & 0.01 & 99.8 \\
\hline 6 & & 1.50 & 2.98 & 1.52 & 35.5 & 1.81 & 97.7 & 0.44 & 99.2 & 0.04 & 99.9 & 0.00 & 100.0 \\
\hline 7 & & 2.50 & 2.51 & 1.99 & 45.7 & 1.17 & \begin{tabular}{|l}
98.5 \\
\end{tabular} & 0.03 & 99.9 & 0.00 & \begin{tabular}{|l|}
100.0 \\
\end{tabular} & \begin{tabular}{|l|l} 
\\
\end{tabular} & 100.0 \\
\hline 8 & & 4.00 & 2.03 & 2.47 & 56.1 & 0.36 & \begin{tabular}{|l|l}
99.6 \\
\end{tabular} & 0.00 & 100.0 & 0.00 & $\mid$\begin{tabular}{|l}
100.0 \\
\end{tabular} & \begin{tabular}{|l|l|} 
\\
\end{tabular} & 100.0 \\
\hline 9 & & 5.00 & 1.64 & 2.86 & 64.5 & 0.02 & 100.0 & 0.00 & 100.0 & 0.00 & 100.0 & 0.00 & 100.0 \\
\hline 10 & & 6.00 & 1.30 & 3.20 & 71.9 & 0.00 & 100.0 & 0.00 & 100.0 & 0.00 & 100.0 & 0.00 & 100.0 \\
\hline 11 & & 7.70 & 0.98 & 3.52 & 78.8 & 0.00 & $\mid$\begin{tabular}{|l}
100.0 \\
\end{tabular} & 0.00 & 100.0 & 0.00 & 100.0 & 0.00 & 100.0 \\
\hline 12 & & 10.00 & 0.69 & 3.81 & 85.1 & 0.00 & 100.0 & 0.00 & 100.0 & 0.00 & 100.0 & 0.00 & 100.0 \\
\hline & & 15.00 & \begin{tabular}{|l|l|}
0.59 \\
\end{tabular} & 3.91 & \begin{tabular}{|l|l}
87.2 \\
\end{tabular} & 0.00 & \begin{tabular}{|l}
100.0 \\
\end{tabular} & 0.00 & 100.0 & 0.00 & $\mid 100.0$ & 0.00 & 100.0 \\
\hline 13 & & 21.00 & 0.54 & 3.96 & \begin{tabular}{|l}
88.3 \\
\end{tabular} & 0.00 & \begin{tabular}{|l|l}
100.0 \\
\end{tabular} & 0.00 & 100.0 & 0.00 & \begin{tabular}{|l|}
100.0 \\
\end{tabular} & \begin{tabular}{|l|l} 
\\
\end{tabular} & 100.0 \\
\hline
\end{tabular}


J. Environ. Sci.

Institute of Environmental Studies and Research - Ain Shams University

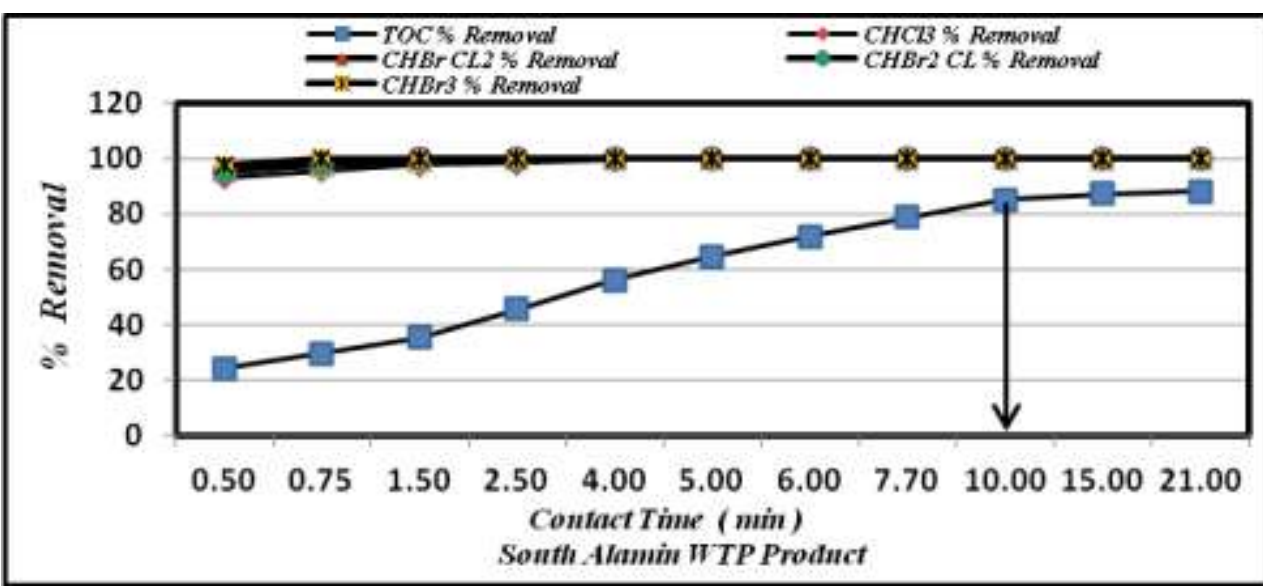

Figure (6): \% removal variation of Analytes from produced water of South Alamein WTP with different contact time with GAC in glass column during August 2017.

4.1 FIXED-BED Column studies on South Alamein WTP: The produced drinking water from South Alamein WTP (during August 2017) passed through the continuous flow glass apparatus ( $2 \mathrm{~cm} \mathrm{ID);} \mathrm{packed} \mathrm{with} 25 \mathrm{~g}$ GAC, GAC bed depth height was $16 \mathrm{~cm}$, Fig (1). The flow rate adjusted using a fine restrictor at the end of column to $5 \mathrm{ml} / \mathrm{min}$ (7.2 L/Day), and contact time (10.0 min). A daily water samples collected from the container of the column output (7.2 L/day) to measure (DBPs-VOCs) and TOC for estimating the maximum adsorption capacities for each parameter with GAC, and the volume of water at which GAC well be exhausted for each parameter. The initial concentrations of each parameter measured daily before entering the column, and the mean values at the end of experiment taken as the initial concentration $\mathrm{C}_{\mathrm{o}}$ in the calculations. 
Table (3) shows the results of this experiment, where $\mathrm{x}$ is the amount of adsorbate from $7.2 \mathrm{~L}, \mathrm{x} / \mathrm{m}$ is the mass of adsorbate from $7.2 \mathrm{~L}$ per unit mass of adsorbent (mg adsorbate/g GAC).

Fig (7) shows a breakthrough diagram for the total parameters of DBPsVOCs.

Adsorption capacity $\left(\mathrm{q}_{\mathrm{e}}\right)$, is the amount of DBPs-VOCs adsorbed on $\mathrm{GAC}$ in equilibrium calculated as follows:

$$
q_{e}=\frac{\left(C_{0}-C_{e}\right) V}{W},
$$

Where $q e(\mathrm{mg} / \mathrm{g})$ or $(\mu \mathrm{g} / \mathrm{g})$ is the amount of analyte adsorbed at equilibrium. $\mathrm{C}_{\mathrm{o}}$ and $\mathrm{C}_{\mathrm{e}}(\mathrm{mg} / \mathrm{l})$ or $(\mu \mathrm{g} / \mathrm{l})$, are the liquid-phase concentrations of DBP-VOCs at initial and equilibrium conditions, respectively. (L) Is the volume of the solution and $\mathrm{W}(\mathrm{g})$ is the mass of activated carbon used. 
J. Environ. Sci.

Institute of Environmental Studies and Research - Ain Shams University

Table (3): Equilibrium concentrations $\mathrm{C}_{\mathrm{e}}$ of Analytes from produced water of South Alamein WTP and the amount adsorbed per unit mass of GAC at constant contact time 10 min with GAC in glass column during August 2017.

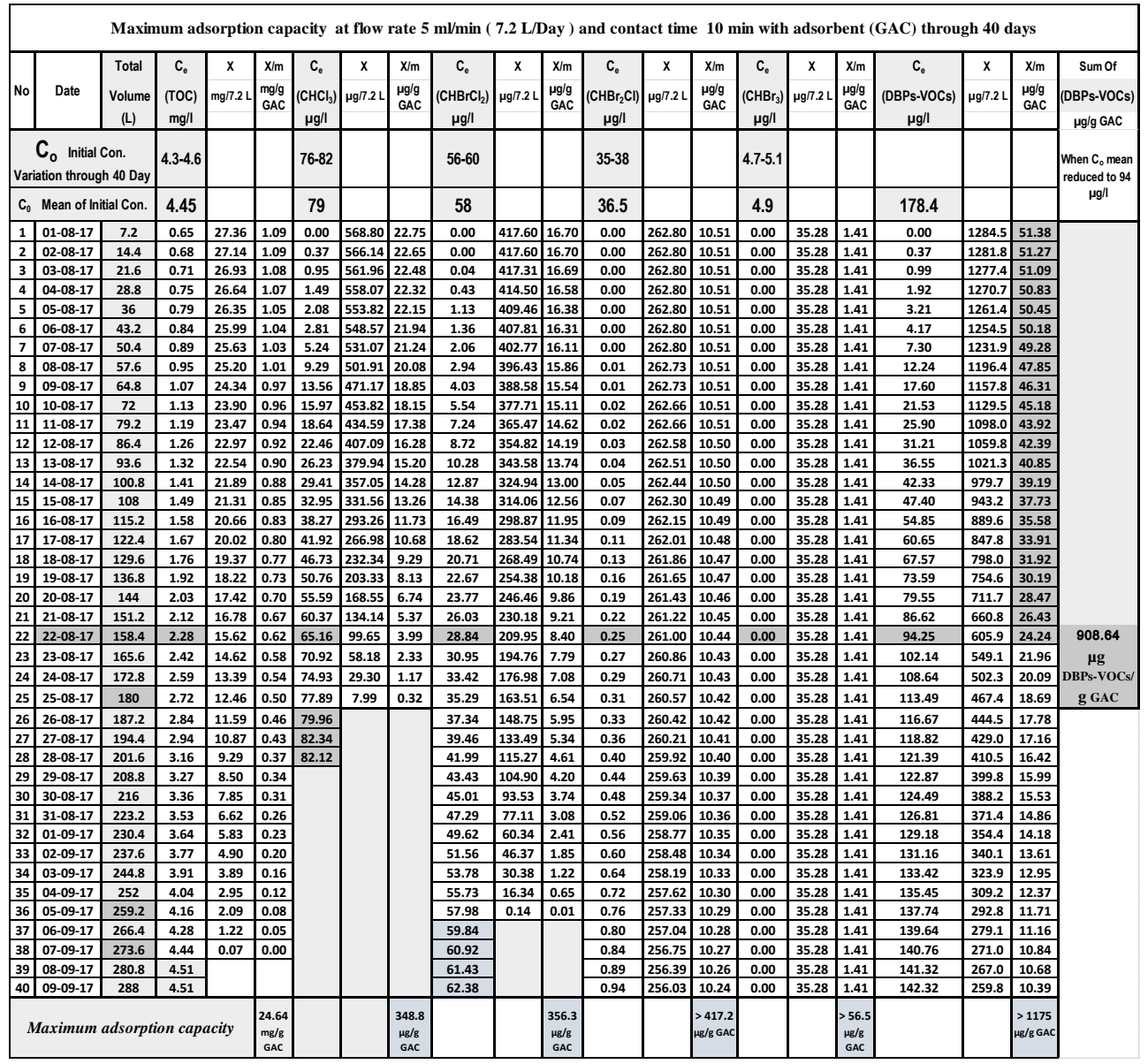

Where $\mathrm{x}$ is the amount of adsorbate from $7.2 \mathrm{~L}, \mathrm{x} / \mathrm{m}$ is the mass of adsorbate from

7.2 L per unit mass of adsorbent (mg adsorbate/g GAC). 
From the above results (Table, 3) we find that, the maximum adsorption capacity of TOC is $24.52 \mathrm{mg} /$ (g GAC), maximum adsorption capacity of chloroform, is $348 \mu \mathrm{g} / \mathrm{g}$ GAC), maximum adsorption capacity of bromodichloromethane is $359 \mu \mathrm{g} /(\mathrm{g}$ GAC). The maximum adsorption capacities of dibromochloromethane and bromoform did not reach the maximum at the end of experiment after 40 days, (adsorption capacity of dibromochloromethane is more than $417 \mu \mathrm{g} /(\mathrm{g}$ GAC), and that for bromoform is more than $56 \mu \mathrm{g} /$ (g GAC). The output of the column was free of bromoform until the end of the experiment after 40 days. This estimation assumes a constant influent concentration of analytes and neglects the influence of competitive adsorption.

The amount of total values of (DBPs-VOCs) is reduced from $178.4 \mu \mathrm{g} / \mathrm{l}$ (initial concentration before GAC) to $94.25 \mu \mathrm{g} / \mathrm{l}$ after passing $158.4 \mathrm{~L}$ of produced water of South Alamein WTP which is below enough the maximum permissible limit $(100 \mu \mathrm{g} / \mathrm{l})$.

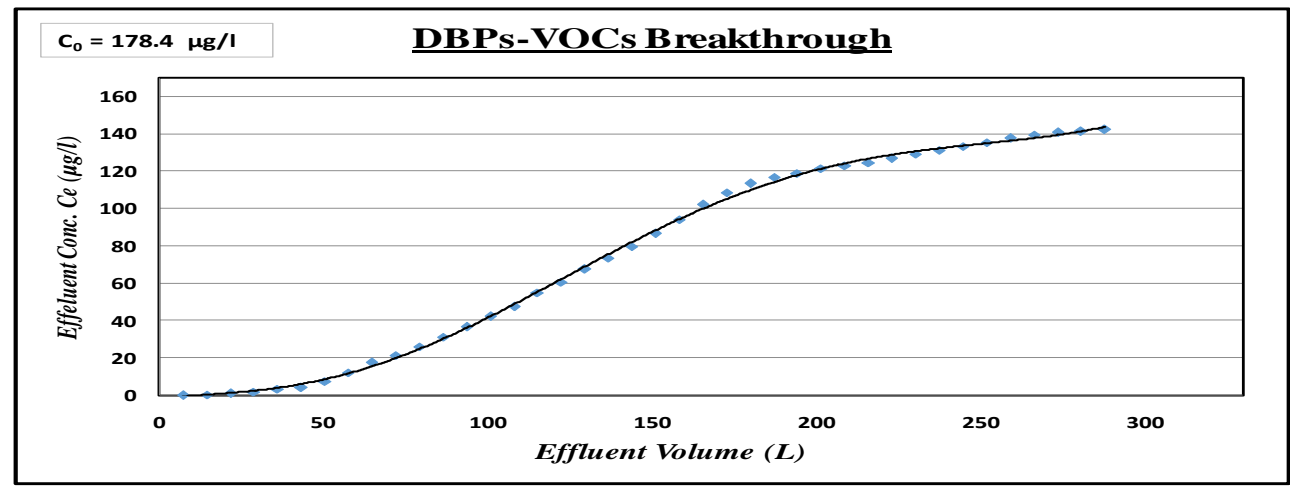

Figure (7): Variation of effluent concentration $\mathrm{C}_{\mathrm{e}}$ of (DBPs-VOCs) after passing through GAC glass column at constant contact time 10 min from the produced water of South Alamein WTP with volume during August 2017. 
As shown in Figure (7), the concentration of total values of (DBPsVOCs) measured in the effluent of the glass column (Cout) was near to 0.0 $\mu \mathrm{g} / \mathrm{l}$, then the concentration increases gradually until it reaches a value (about $94 \mu \mathrm{g} / \mathrm{l})$, which is less than the Egyptian guidelines $(100 \mu \mathrm{g} / \mathrm{l})$. The entire amount of GAC (25 g) should be changed after passing $158.4 \mathrm{~L}$ from the produced water of South Alamein WTP, at which the total values of (DBPsVOCs) is reduced from $178 \mu \mathrm{g} / \mathrm{l}$ to $94 \mu \mathrm{g} / \mathrm{l}$, at constant temperature, $\mathrm{pH}$ and contact time 10 min. (Table, 3).

For DBPs-VOCs (formed during disinfection process), according to table (3), the maximum adsorption capacity of adsorbent GAC to adsorbate (DBPsVOCs $)$ is $908.64 \mu \mathrm{g} / \mathrm{g}(0.90864 \mathrm{~g} / \mathrm{kg})$. To reduce the initial concentration $\mathrm{C}_{\mathrm{o}}$ from $178.4 \mu \mathrm{g} / \mathrm{l}$ (above the permissible limit $100 \mu \mathrm{g} / \mathrm{l}$ ) to $94 \mu \mathrm{g} / \mathrm{l}$, about 84.15 $\mu \mathrm{g} / \mathrm{l}$ are adsorbed on the adsorbate $\operatorname{GAC}\left(0.0815 \mathrm{~g} / \mathrm{m}^{3}\right)$ yields $14474 \mathrm{~g} /$ day of (DBPs-VOCs), applied to $498.75-\mathrm{m}^{2}$ cross-section of GAC bed. This crosssection, $2.4 \mathrm{~m}$ deep, contains $1197 \mathrm{~m}^{3}$ of GAC media. Converting this to weight yields $580545 \mathrm{~kg}$ of adsorbent $\left(\mathrm{GAC}\right.$ density $\left.=485 \mathrm{~kg} / \mathrm{m}^{3}\right)$. Therefore, the days required to "load" this adsorbent to equilibrium is:

Days of operation = Total weight of adsorbent $\mathrm{kg} \mathrm{GAC} \mathrm{X}$ equilibrium loading/ Daily load [Eq. 1]

Days of operation $=(580545 \mathrm{~kg})(0.90864 \mathrm{~g} / \mathrm{kg}) / 14474 \mathrm{~g} / \mathrm{day}$

$$
\text { = } 36 \text { Days }
$$

The above results of application of the maximum adsorption capacity of examined parameters in South Alamein WTP are summarized in table (4) with respect to coast of GAC duration. 
Table (4): Summary of important figures when a GAC bed removal is applied in South Alamein WTP.

\begin{tabular}{|c|c|c|c|c|}
\hline \multirow[b]{2}{*}{ For South Alamein WTP } & \multicolumn{4}{|c|}{ Compounds } \\
\hline & $\stackrel{\circlearrowright}{\varrho}$ & 㓂 & 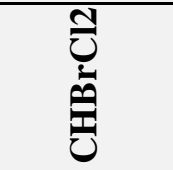 & 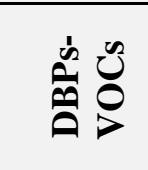 \\
\hline Initial concentration $C_{o}$ & $4.45 \mathrm{mg} / \mathrm{g}$ & $79 \mu \mathrm{g} / \mathrm{g}$ & $58 \mu \mathrm{g} / \mathrm{g}$ & $\begin{array}{l}178.4 \\
\mu \mathrm{g} / \mathrm{g}\end{array}$ \\
\hline Maximum adsorption capacity & $23.55 \mathrm{mg} / \mathrm{g}$ & $150 \mu \mathrm{g} / \mathrm{g}$ & $366 \mu \mathrm{g} / \mathrm{g}$ & $909 \mu \mathrm{g} / \mathrm{g}$ \\
\hline Days of operation & 18.7 & 14.9 & 20.7 & 36 \\
\hline Maximum production & \multicolumn{4}{|c|}{$172000 \mathrm{~m}^{3} /$ day } \\
\hline GAC Weight & \multicolumn{4}{|c|}{581 Ton } \\
\hline Price of GAC & \multicolumn{4}{|c|}{ About $1000 \$$} \\
\hline GAC Coast/36 Days & \multicolumn{4}{|c|}{$581000 \$$} \\
\hline Total GAC Coast/year & \multicolumn{4}{|c|}{ 5.89 Million \$ } \\
\hline Overhead coast $/ \mathrm{m}^{3}$ & \multicolumn{4}{|c|}{$0.094 \$$} \\
\hline
\end{tabular}

\section{CONCLUSIONS}

The study recorded the absence of VOCs contaminant in raw water of both selected sites which indicate that the industrial discharge before Cairo Governorate and along the next branches to arrive the next site over $285 \mathrm{~km}$ include (Nile River - Behery main branch - Noubaria canal - El Nasr canal Elhammam Canal) are not loaded with VOCs contaminants. The average concentrations of VOCs that produced during the treatment process (DBPsVOCs) from Shubra El-Kheima WTP are within the accepted limits during $2016(64 \mu \mathrm{g} / \mathrm{l})$ and below the maximum permissible limit $(100 \mu \mathrm{g} / \mathrm{l})$. The average concentrations of VOCs that produced during the treatment process 
(DBPs-VOCs) from South Alamein WTP do not comply the Egyptian guidelines during $2016(120 \mu \mathrm{g} / \mathrm{l})$ and higher than the maximum permissible limit $(100 \mu \mathrm{g} / \mathrm{l})$.

The average concentration of VOCs that produced during the disinfection process with chlorine (DBPs-VOCs), is not comply with the Egyptian guidelines during 2016, (South Alamein booster $132 \mu \mathrm{g} / \mathrm{l}$, Sidi Abdel Rahman booster $148 \mu \mathrm{g} / \mathrm{l}$, Aldabaa Booster $174 \mu \mathrm{g} / \mathrm{l}$, Fuka Booster $201 \mu \mathrm{g} / \mathrm{l}$, Ras Elhekma Booster $214 \mu \mathrm{g} / \mathrm{l}$ and Garawla Booster $224 \mu \mathrm{g} / \mathrm{l}$ ) which is higher than the maximum permissible limit $(100 \mu \mathrm{g} / \mathrm{l})$.

The increase in VOCs values as we going from South Alamein WTP to the boosters are due to the increase in contact time of treated water with residual chlorine and the extra dose of chlorine in that boosters to compensate the losses that consumed along this distance in reacting with TOC precursor to produce more amount of VOCs .

- GAC could successfully minimize the concentrations of TOC as a main precursor of the produced VOCs from the disinfection process with chlorine and consequently DBPs-VOCs $\left(\mathrm{CHCl}_{3}, \mathrm{CHBrCl}_{2}, \mathrm{CHBr}_{2} \mathrm{Cl}\right.$ and $\left.\mathrm{CHBr}_{3}\right)$.

-The average consumption of GAC is 581 Ton per 36 days of operation in South Alamein WTP where it produces $172000 \mathrm{~m}^{3} /$ day. The average overhead cost of using GAC in South Alamein WTP is $0.094 \$ / \mathrm{m}^{3}$ water.

\section{REFERENCES}

Egyptian guidelines, (2007), Decree (458), "Egyptian guidelines according to Minister of Health and Population decree on the standards and specifications to be met in Drinking water and Household use". 
EPA, (1995), "Environmental protection agency", Method 524.2, "Measurement of purgeable organic compounds in water by capillary column gas chromatography/mass spectrometry".

Haas, C.N. and Aturaliye, D.N. (1999), "Kinetics of electroporation-assisted chlorination of Giardia muris", Water Research, 33:8, 1761-1766.

Hailin, N.Lie, L.Jing, W. Yufei, W. Gang, W. Junhui, H.Zhengping, (2013), "Characterization and assessment of volatile organic compounds (VOCs) emissions from typical industries", Chin. Sci. Bull., 58, 724-730.

Ikem A., (2010), Measurement of volatile organic compounds in bottled and tap waters by purge and trap GC-MS: Are drinking water types different? Journal of Food Composition and Analysis 23, 70-77

Kavcar, P., Odabasi, M., Kitis, M., Inal, F., Sofuoglu, S.C., (2006), Occurrence, oral exposure and risk assessment of volatile organic compounds in drinking water for I' zmir, Water Research 40, 3219-3230.

Kruawal, K., Sacher, F., Werner, A., Muller, J., Knepper, T.P., (2005), Chemical water quality in Thailand and its impacts on the drinking water production in Thailand. The Science of the Total Environment 340, 57-70.

Leivadara, S.V., Nikolaou, A.D., Lekkas, T.D., (2008), Determination of organic compounds in bottled waters. Food Chemistry 108, 277286.

Minister of Health Decree No. 458 of (2007), The standards and specifications to be met in Drinking water and Household use.

Panyakapo, M., Soontornchai, S., Paopuree, P., (2008), Cancer risk assessment from exposure to trihalomethanes in tap water and swimming pool water, Journal of Environmental Sciences., 20, 372-378.

Panyapinyopol, B., Marhaba, T.F., Kanokkantapong, V., Pavasant, P., (2005), "Characterization of precursors to trihalomethanes formation in Bangkok source water", Journal of Hazardous Materials, 120, 229-236

Salama, T.E. (2004), " Analytical Studies on Some Haloacetic Acids and Dalapon in Drinking \& Wastewater " MSc, Chemistry Department Faculty of Science (Al - Azhar University) Cairo Egypt P $2 \rightarrow 5,7,8,24$ 
Sun, Y.X., Wu, Y.Q., Hu, H.Y. and Tian, J, (2009), "Effects of Operating Conditions on THMs and HAAs Formation during Wastewater Chlorination", Journal of Hazardous Materials, 168, 1290-1295, http://dx.doi.org/10.1016/j.jhazmat.2009.03.013

USEPA (US Environmental Protection Agency), (1998), Disinfectants and Disinfection By-products.Final Rule.Fed.Reg. 63:241:69390.

Uyak, V., (2006), Multi-pathway risk assessment of trihalomethanes exposure in Istanbul drinking water supplies. Environment International 32, 12-21.

Wang, G., Deng, Y., Lin, T., (2007), Cancer risk assessment from trihalomethanes in drinking water. The Science of The Total Environment 387, 86-95.

Water Quality Report, (2007), City of Columbia, Missouri, http://www.gocolumbiamo.com/WaterandLight/Documents/broch ure.pdf (accessed 17.04.09)

WHO (2004), "Guidelines for drinking water quality", 3rd Ed", Geneva: Volume 1

WHO (2011), "Guidelines for drinking water quality", 4th Ed", Geneva: Volume 1.

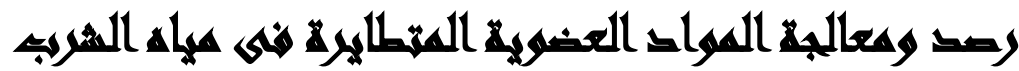

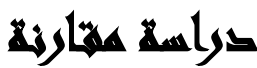

\section{$[Y]$}

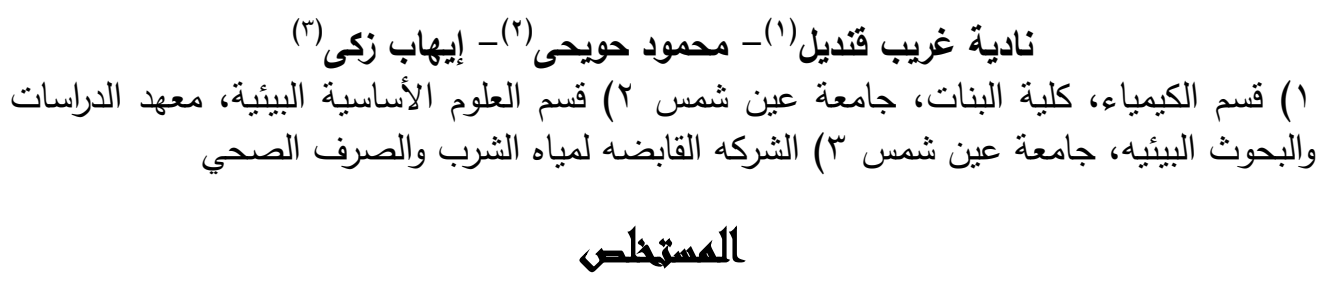

تمنل المركبات العضوية المنطايرة في مباه الثرب تأثنرا سلبيا على صحة الإنسان والبيئة

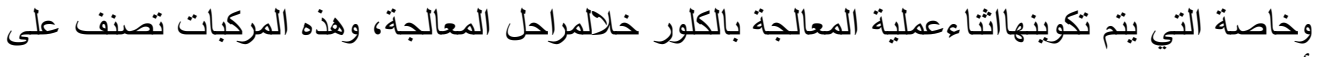

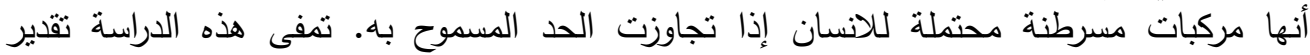

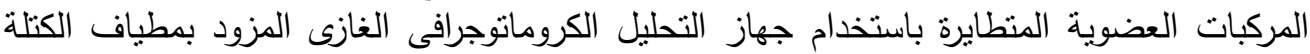

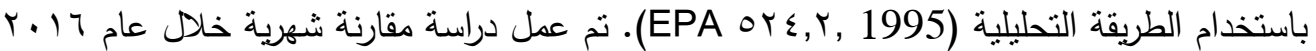


للمركبات العضوية المتطايرة في كل من محطتى شبرا الخيمة (على بعد كيلومتر واحد من نهر النيل

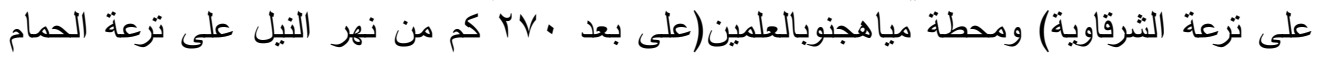

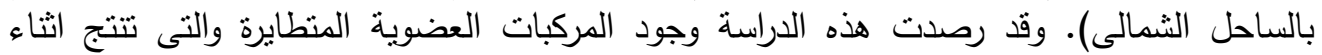
استخدام الكلور في مراحل المعالجة (DBPs-VOCs)(CHClBr و وتجاوزت هذه القيم الحد المسموح به في المياه المعالجة لمحطة مياه جنوب العلمين. وقد المدات

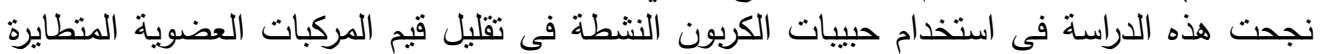

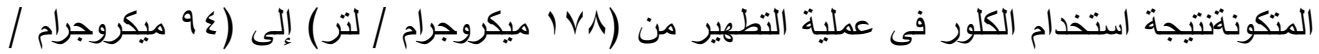

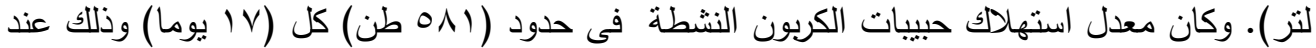
تشغيل المحطة على اقصى سعة انتاجية لها ( ... IVT متر مكعب اليوم). 